\title{
EXPERIMENTAL INVESTIGATION OF LIGHT WEIGHT BRICK BY PARTIAL REPLACEMENT OF CLAY WITH NATURAL WASTE MATERIAL
}

\author{
SERMILIRONGPIPI ${ }^{1} \&$ PRINCE SHARMA $^{2}$ \\ ${ }^{I}$ ME Student, Department of Civil Engineering, Chandigarh University, Mohali, Punjab, India \\ ${ }^{2}$ Assistant Professor, Department of Civil Engineering, Chandigarh University, Mohali, Punjab, India
}

\begin{abstract}
The use of new materials for making bricks by partially replacing the clay with natural waste material for making conventional bricks will help the environment for sustainable development, as low amount of soil will be used in making brick and it will be cheaper in cost compared to conventional bricks. For example in today's time the availability of good fertile soil is decreasing day by day due to many industries and apartments and from these industries many waste materials are produced in daily basis so if we can use the waste products for making bricks from the industries as these products are no use for them we can save soil and money. The usage of waste materials from the industry will help the environment to be clean and healthy for the nearby beings and will keep the mother earth safe. In this investigation, researchers are using marble powder and rice husk ash which has been collected from nearby industries, the waste materials will be partially replaced in proportion of $5 \%, 15 \%, 25 \%, 35 \%$ by weight of samples in clay.

KEYWORDS: Rice Husk Ash, Marble Powder, Clay
\end{abstract}

Received: Jun 10, 2020; Accepted: Jun 30, 2020; Published: Jul 21, 2020; Paper Id.: IJMPERDJUN2020406

\section{INTRODUCTION}

The increase in development of infrastructure in the developing countries more land is used for building houses, apartments and manufacturing industries due to which we are losing more fertile soil day by day which is harming the nature and the beings living that area, if we continue to exploit the fertile land we are going to lose all the land and sustainable development will be harder for our future. The increase in industrial waste is also hampering our mother earth as the waste material are dumped in landfills and water streams nearby the industries making the life of aquatic life harder. The productive reuse of the waste materials represents the way of solving the major concern for solid waste management. In this investigation rise husk ash and marble powder was used to find out the feasibility with clay as a partial replacement. These waste materials that are used have been collected from nearby industries. By using this waste product we are decreasing the use of soil relatively as we are mixing the waste products in specific ratio to attain the desired result. This investigation is done to attain the following goals:-

- $\quad$ To minimize the use of fertile soil.

- To maximize the use of natural waste materials that we usually discard from manufacturing industries. 


\section{OBJECTIVE OF THE STUDY}

The main objective of this investigation is to study about the reuse of natural waste material i.e. RHA (Rice Husk Ash) and marble powder in brick to make the brick more light weight compared to the conventional brick and to perform the following test:-

- $\quad$ Compressive Strength

- Water Absorption Test

- Efflorescence Test

\section{METHODOLOGY}

\section{Material}

\section{Rice Husk Ash}

The rice husk ash was collected from rice mill which is located at Kharar, Punjab, India. The chemical and physical properties of rice husk ash are as follows:-

Table 1: General RHA Properties

\begin{tabular}{|c|l|c|}
\hline Sl. No. & \multicolumn{1}{|c|}{ Parameters } & Values \\
\hline 1 & Fineness Passing Through 45 Micron & $95 \%$ \\
\hline 2 & Specific Gravity $\left(\mathrm{g} / \mathrm{cm}^{3}\right)$ & 2.07 \\
\hline 3 & Specific Surface $\left(\mathrm{Nitrogen}^{3}\right.$ Absorption) $\mathrm{m}^{2} / \mathrm{kg}$ & 27500 \\
\hline 4 & Silicon Dioxide $\left(\mathrm{SiO}_{2}\right)$ & $87.30 \%$ \\
\hline 5 & Aluminum Oxide $\left(\mathrm{Al}_{2} \mathrm{O}_{3}\right)$ & $0.16 \%$ \\
\hline 6 & Ferric Oxide $\left(\mathrm{Fe}_{2} \mathrm{O}_{3}\right)$ & $0.17 \%$ \\
\hline 7 & Calcium Oxide $(\mathrm{CaO})$ & $0.52 \%$ \\
\hline 8 & Magnesium Oxide $(\mathrm{MgO})$ & $0.37 \%$ \\
\hline 9 & Sulphur Trioxide $\left(\mathrm{SO}_{3}\right)$ & $0.26 \%$ \\
\hline 10 & Carbon $(\mathrm{C})$ & $5.96 \%$ \\
\hline 11 & Loss of Iignition & $5.48 \%$ \\
\hline 12 & Pozzolanic Activity & $86 \%$ \\
\hline 13 & Particle Size $(\mu \mathrm{m})$ & 5 \\
\hline
\end{tabular}

\section{Marble Powder}

The marble powder was collected from Ram Krishna marbles and tiles, Chandigarh, India. The chemical and physical properties of marble powder are as follows:-

Table 2: General Properties of Marble Powder

\begin{tabular}{|c|l|c|}
\hline Sl. No. & \multicolumn{1}{|c|}{ Properties } & Values \\
\hline 1 & Specific Gravity $\left(\mathrm{g} / \mathrm{cm}^{3}\right)$ & 2.75 \\
\hline 2 & Surface by Blaine $\left(\mathrm{cm}^{2} / \mathrm{g}\right)$ & 4376 \\
\hline 3 & $\mathrm{SiO}_{2}$ & $0.96 \%$ \\
\hline 4 & $\mathrm{Fe}_{2} \mathrm{O}_{3}$ & $0.49 \%$ \\
\hline 5 & $\mathrm{CaCO}_{3}$ & $97.38 \%$ \\
\hline
\end{tabular}

\section{Soil}

The soil was collected from the brick kiln at Bhatheri, Fathegarh Sahib, Punjab, India where the desired brick was molded and burnt. The properties of soil are as follows:- 
Table 3: General Properties of Soil

\begin{tabular}{|c|l|c|}
\hline Sl. No. & \multicolumn{1}{|c|}{ Properties } & Values \\
\hline 1 & Liquid Limit & $47 \%$ \\
\hline 2 & Plastic Limit & $25 \%$ \\
\hline 3 & Plasticity Index & $22 \%$ \\
\hline 4 & Specific Gravity & $26.9\left(\mathrm{~g} / \mathrm{cm}^{3}\right)$ \\
\hline
\end{tabular}

\section{Methodology}

\section{- Dry Mixing of Samples with Clay}

The samples collected from different location i.e. RHA (Rice Husk Ash), marble powder are mixed together in the clay in a proportion of $5 \%, 15 \%, 25 \%$ and $35 \%$ as the waste materials are partially replacing the clay to minimize the use of clay.

To measure the samples we are using electronic weighing machine.

\section{- Wet Mixing of Samples with Clay}

When the dry mixing of aforementioned samples is completed then water is added to the mix in a desired portion to attain a good bond between the samples and clay.

Note that the sample should not be too mushy nor to hard.

\section{- Casting of Brick}

The non-modular brick samples of size 230X110X70 mm (Indian Standard: 1077, 1997) have been casted using soil, rice husk ash and marble powder in proportion of $5 \%, 15 \%, 25 \%, 35 \%$ by weight. The clean mold was filled with the above mix without allowing any air bubble, since the brick has been cast by hand so no pressure has been applied on the mold.

\section{- Drying of Molded Bricks}

The molded bricks were kept for drying under the sun for 15 days, so that the moisture inside the brick gets dry sufficiently, the drying of brick is necessary because if we place the brick inside the kiln then cracks can form in different part of the brick which we don't want. The drying of brick is also helpful in handling the brick and stocking in the burning kiln.

\section{- Burning of Bricks}

The sun dried brick is then placed inside the kiln to obtain hardness and to increase the density of the brick. The burning and cooling period of the brick is between 18 days to 20 days and is burnt at a temperature between $1800 \mathrm{~F}$ to $2400 \mathrm{~F}$.

\section{RESULT AND DISCUSSION}

We have taken various sample bricks which are made from RHA, marble powder and clay in proportion of 5\%, $15 \%, 25 \%$, $35 \%$ to do various test in order to justify the sampled bricks.

\section{Compressive Strength}

During the test we have found that if the sample value of RHA, marble powder and RHA+Marble powder is greater than $5 \%$ then the compressive strength value was showing lower, so by this test we found that if the samples value is less than or equal to $5 \%$ the compressive value is higher. The study was based on IS: 3495 (Part 1). The following graph (Fig. 1) shows the result:- 


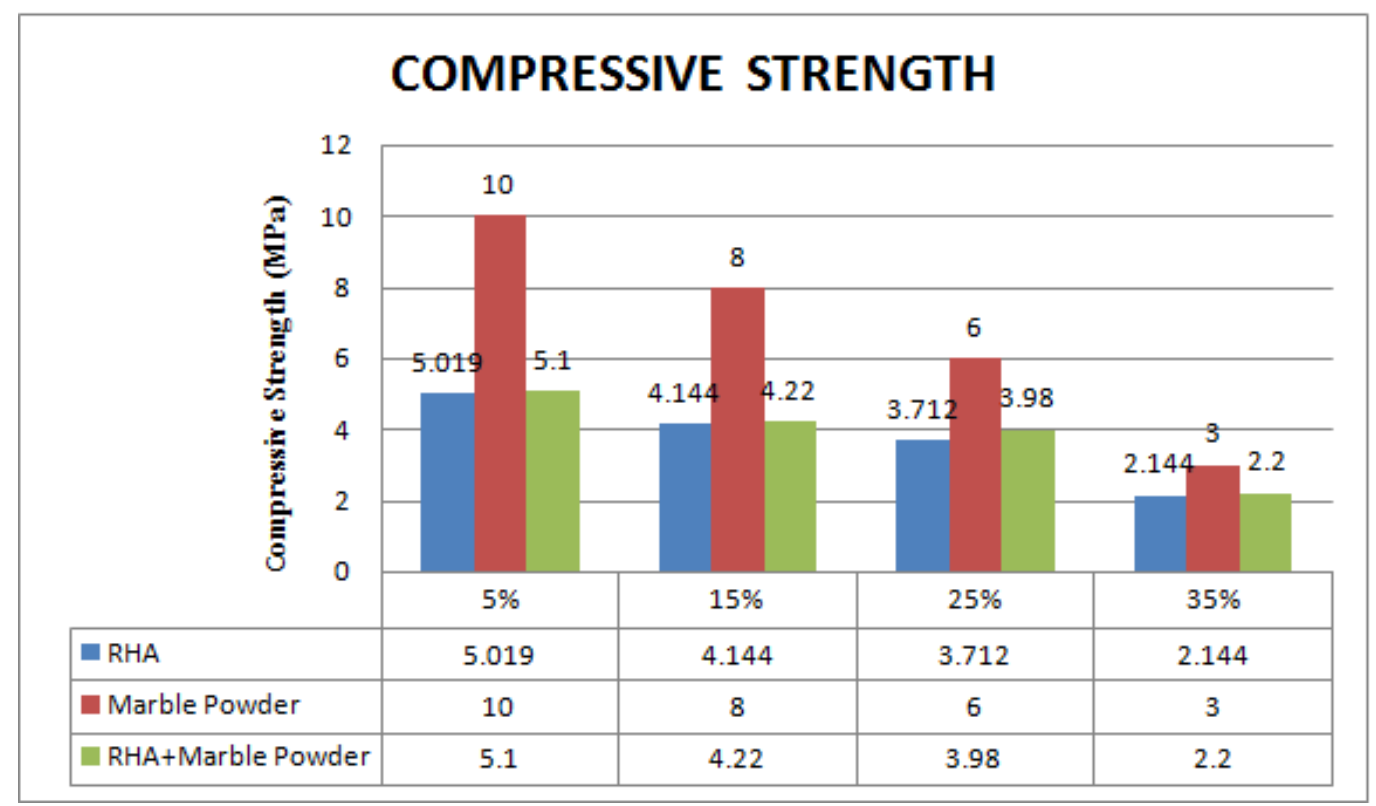

Figure 1: Compressive Strength of the Burnt Sampled Brick.

\section{Water Absorption Test}

The water absorption test was done according to IS: 3495 (Part 2). The water absorption test was done by infusing the collected waste samples at a proportion of $5 \%, 15 \%, 25 \%$ and $35 \%$.

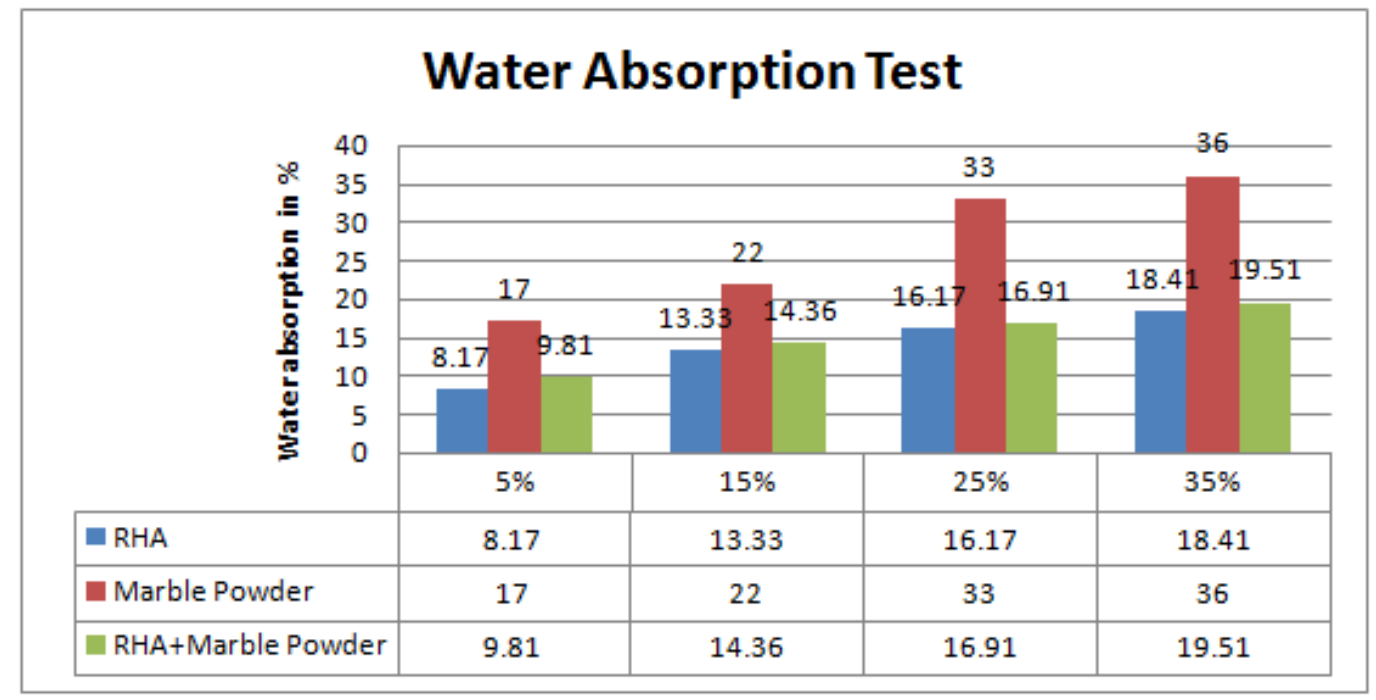

Figure 2: Water Absorption Test of Burnt Sampled Brick.

\section{Efflorescence Test}

The efflorescence test was performed according to IS: 3495 (Part 3). The efflorescence may be sourced due to alkaline salts present in the brick. If the percentage of these alkaline salts is higher it may result in the formation of cracks or disintegration of brick. 
Table 4: Result of Efflorescence Test

\begin{tabular}{|c|l|c|c|c|c|c|}
\hline Sl. No. & \multicolumn{1}{|c|}{ Brick Type } & Nil & Slight & Moderate & Heavy & Serious \\
\hline 1 & RHA & - & Yes & - & - & - \\
\hline 2 & Marble Powder & - & Yes & - & - & - \\
\hline 3 & RHA+Marble Powder & - & Yes & - & - & - \\
\hline
\end{tabular}

\section{Comparison with Conventional Brick}

Table 5: Brick Containing RHA and Clay

\begin{tabular}{|c|c|c|c|}
\hline Sl. No. & Weight of Soil in (\%) & Weight of Waste in (\%) & Burnt Brick $\mathbf{( K g )}$ \\
\hline 1 & 95 & 5 & 2.00 \\
\hline 2 & 85 & 15 & 1.93 \\
\hline 3 & 75 & 25 & 1.7 \\
\hline 4 & 65 & 35 & 1.4 \\
\hline
\end{tabular}

Table 6: Brick Containing Marble Powder

\begin{tabular}{|c|c|c|c|}
\hline Sl. No. & Weight of Soil in (\%) & Weight of Waste in (\%) & Burnt Brick (Kg) \\
\hline 1 & 95 & 5 & 2.71 \\
\hline 2 & 85 & 15 & 2.4 \\
\hline 3 & 75 & 25 & 2.1 \\
\hline 4 & 65 & 35 & 1.8 \\
\hline
\end{tabular}

Table 7: Brick Containing RHA and Marble Powder

\begin{tabular}{|c|c|c|c|}
\hline Sl. No. & Weight of Soil in (\%) & Weight of Waste in (\%) & Burnt Brick (Kg) \\
\hline 1 & 95 & 5 & 2.35 \\
\hline 2 & 85 & 15 & 2.13 \\
\hline 3 & 75 & 25 & 1.9 \\
\hline 4 & 65 & 35 & 1.6 \\
\hline
\end{tabular}

On comparing from above table 5,6 and 7 with the conventional or traditional brick we found that these sampled burnt bricks are lighter whereas the weight of a conventional brick is around $3.1 \mathrm{~kg}$ hence it proved that this bricks are light weight bricks.

\section{CONCLUSIONS}

- From the investigation we found that if the quantity of waste sample is greater than $5 \%$ then the compressive strength of brick is affecting.

- In the water absorption test it was found that if the value of used sample is between 5\% - 10\% then it giving good result comparing to other sample values.

- In the efflorescence test it was found that the only slight alkaline salts are present so the brick is suitable to use in building.

- $\quad$ As these sampled burnt bricks are light in weight these are easy to handle comparing to traditional brick.

\section{REFERANCES}

1. Carter, G. W., Cannor, A. M., \&Mansell, D. S. (1982). Properties of bricks incorporating unground rice husks. Building and Environment, 17(4), 285-291. doi:10.1016/0360-1323(82)90021-x-paper 7

2. Rahman, M. A. (1987). Properties of clay-sand-rice husk ash mixed bricks. International Journal of Cement Composites and Lightweight Concrete, 9(2), 105-108. doi:10.1016/0262-5075(87)90026-1 
3. Chindaprasirt, P., Jaturapitakkul, C., \& Rattanasak, U. (2009). Influence of fineness of rice husk ash and additives on the properties of lightweight aggregate. Fuel, 88(1), 158-162. doi:10.1016/j.fuel.2008.07.024 - paper 5

4. Sutas, J., Mana, A., \& Pitak, L. (2012). Effect of Rice Husk and Rice Husk Ash to Properties of Bricks. Procedia Engineering, 32, 1061-1067. doi:10.1016/j.proeng.2012.02.055 - paper 2

5. Bilgin, N., Yeprem, H. A., Arslan, S., Bilgin, A., Günay, E., \& Marşoglu, M. (2012). Use of waste marble powder in brick industry. Construction and Building Materials, 29, 449-457. doi:10.1016/j.conbuildmat.2011.10.011 - paper8

6. Raut, S., Ralegaonkar, R., \& Mandavgane, S. (2013). Utilization of recycle paper mill residue and rice husk ash in production of light weight bricks. Archives of Civil and Mechanical Engineering, 13(2), 269-275. doi:10.1016/j.acme.2012.12.006 -paper 1

7. Görhan, G., \& Şimşek, O. (2013). Porous clay bricks manufactured with rice husks. Construction and Building Materials, 40, 390-396. doi:10.1016/j.conbuildmat.2012.09.110 - paper 3

8. Zhang, L. (2013). Production of bricks from waste materials - A review. Construction and Building Materials, 47, 643655. doi:10.1016/j.conbuildmat.2013.05.043 - paper 10

9. R.Nithiya, Chris Anto.L, K.R.Vinodh, Dr.C.Anbalagan (2016), Experimental investigation on bricks by using various waste materials, Vol-06, Issue 03 January 2016.

10. Yeşilay, S., Çakl, M., \& Ergun, H. (2017). Usage of marble wastes in traditional artistic stoneware clay body. Ceramics International, 43(12), 8912-8921. doi:10.1016/j.ceramint.2017.04.028 - paper 9

11. G. Balaji, G. Sanjivkrishnan, R. Jayaprakash raj, M. Balakrishnan J. Harikaran (2017), Preparation of Alternative Bricks by using wood ash and quarry dust, Volume 4, Issue 3, March-2017.

12. Raju Sarkar, Ankur Mudgal, Ritesh Kurar (2017), Use of paper mill waste for brick making, Issue 13 November 2017.

13. Prof. Roshan S. Satpute, Prof. Niklesh R. Murekar, Prof. Manish M. Chaudhari (2017), Using Waste Material for Making Light Weight Bricks, Volume: 5 Issue: 1(Special Issue 21-22 January 2017).

14. Prof. Vivek R. Kasar, Namrata S. Tikhe, Sneha V. Dhanawade, Sunil A. Dhanawade, Sumit R. Gosavi (2018), Reuse of natural waste material(coconut waste) making for light weight bricks, Vol 05 Issue-04, April 2018.

15. Abhishek Chanchal and Ritesh Jain (2018), A review on possibility of bricks with municipal solid waste, Issue 05, 2018

16. Dr. S. Krishnaiah and S.V. Giri Babu (2018), Manufacturing of Eco-Friendly Brick: A Critical Review, Volume, 08 || Issue, 2\| February - 2018 .

17. Kumar, D. Manoj, G. S. Dattatreya, and N. Krishnarjun Rao. "Synthesis Characterization and Mechanical Behavior of Rice Husk Ash Reinforced Al-20mg 10 CU Alloy Matrix Hybrid Composites." International Journal of Mechanical and Production Engineering Research and Development (IJMPERD) 8.1 (2018): 111-118.

18. Reddy, B. Damodhara, et al. "Effect of rice husk ash on the properties of ordinary Portland cement and Portland slag cement with and without super plasticizers." International Journal of Civil, Structural, Environmental and Infrastructure Engineering Research and Development (IJCSEIERD) 3.2 (2013): 1-8.

19. Rasheed, Laith Sh, M. Laith, and Ridha Mahmmoud. "Clay Brick Waste as Internal Curing Agent in Normal Weight Concrete." International Journal of Civil Engineering (IJCE) 2.5 (2013):45-52. 
20. Ash-Shu'ara, Marafa Salman, and Ajayi Wale. "Effect of Addition of Coarse Sand Particles on Engineering Properties of Clay Soil." International Journal of Civil, Structural, Environmental and Infrastructure Engineering Research and Development (IJCSEIERD) 8.4 (2018):23-30.

21. Ropo, Oyetunji Oluremilekun, Pele Babatope Olabanji, and Orisawayi Abimbola Oluwatayo. "A Comparative Study on Refractory Properties of Dolomite Using Clay as Additives." International Journal of Mechanical Engineering (IJME) 7.6 (2018):5-10 

